\title{
Effect of Micronutrients on Yield and Yield Attributes of Hybrid Rice under Boro Cultivation in Lower Gangetic Alluvial Zone
}

\author{
Shirshendu Samanta ${ }^{1 *}$, Augustina Saha ${ }^{1}$ and Nilanjan Deb ${ }^{2}$ \\ ${ }^{1}$ Department of Agronomy, UBKV, Pundibari - 736165, Cooch Behar, West Bengal, India \\ ${ }^{2}$ Department of Agronomy, Institute of Agricultural science, Calcutta University, \\ Kolkata-19, West Bengal, India \\ *Corresponding author
}

\section{A B S T R A C T}

Keywords

Ammonium molybdate, Boro cultivation, Foliar application, Hybrid rice, Micronutrient.

Article Info

Accepted:

26 September 2017

Available Online:

10 October 2017
A field experiment was conducted during 2013-14 at Agricultural Experimental Farm of Calcutta University at Baraipur, 24-Paraganas (south), Kolkata to study the effect of micronutrient on yield and yield attributes of hybrid rice under boro cultivation in lower gangetic alluvial zone. NPK (40/120:60:60) $+\mathrm{ZnSO}_{4}+$ Ammonium molybdate + Disodium-tetrahydrateoctaborate as foliar application at active tillering stage and panicle initiation stage respectively of hybrid rice crop growth have profound influence on the yield parameters such as grain yield (6.54t/ha), straw yield (6.79 t/ha) and biological yield (13.33 t/ha). Harvest index (49.07) was higher in NPK (40/120:60:60) + Ammonium molybdate + Di-sodium-tetrahydrateoctaborate. The yield attributing characters such as no. of panicles $\mathrm{m}^{-1}(10.838)$ and filled grains panicle ${ }^{-1}$ (99.00) were higher in the same treatment although no. of unfilled grains panicle ${ }^{-1}$ (15.00) was less as compared to others. Length of panicle $(27.50 \mathrm{~cm})$ and total no. of grains panicle ${ }^{-1}(120.33)$ were increased due to NPK (40/120:60:60) $+\mathrm{ZnSO}_{4}+$ Ammonium molybdate at active tilleringstage. Test weight $(22.35 \mathrm{~g})$ was higher in NPK (40/120:60:60) $+\mathrm{ZnSO}_{4}+$ Di-sodiumtetrahydrateoctaborate applied in panicle initiation stage.

\section{Introduction}

Rice (Oryza sativa L.) is the premier food crop for the majority population in the world. It contributes $80 \%$ of the calories in the daily diet. Almost $90 \%$ of the rice is produced and consumed in Asia, and 96\% in developing countries. India, the country having the largest rice area in the world has only $41 \%$ of the productivity reached in USA and $48 \%$ of that in China (Prasad and Pandey, 2005). However, India has the largest area (43.91 M.ha) under rice in the world, followed by China (31.5 M.ha.). Rice occupies $46.5 \%$ of the area under cereals, contributing $42 \%$ of the total food grain production in India (Singhal, 2006). In West Bengal, rice is grown in about 5.84 million hectares contributing $14.50 \%$ share of the India's rice area and ranks first producing 14.39 million tonnnes i.e. $19.81 \%$ of India's total production and average yield comes to 2.50 tonnes per hectares. $\mathrm{Zn}$ has synergistic effect with $\mathrm{N}$ in rice. $\mathrm{Zn}$ plays an important role in nitrogen metabolism, protein synthesis (Alloway, 2008). Thus, for higher productivity, optimum dose of $\mathrm{Zn}$ application is essential to meet the demand of rice plant. 
Nitrogen plays the most important role for realizing higher yield potential of rice (Sharma and Das, 1994).Considering the fact that growth intimately connected with the productivity of the crop, a critical analysis of various growth parameters influence by the application of combine effect of nitrogen, phosphorus and zinc with molybdenum responded on crop growth and productivity, the rate of increase in height accelerated, uptake of nutrients and which inturn increased the yield and yield attributing characters(Sen and Dasgupta, 1969).

\section{Materials and Methods}

The field experiment was conducted during rabi season of 2013-2014at the Agricultural Experimental Farm of Calcutta University at Baraipur, 24-Paraganas (south). The soil was clay loam with $\mathrm{pH}-7.0$ having organic carbon $0.725 \%$, Total $\mathrm{N} 0.18 \%, \mathrm{P}_{2} \mathrm{O}_{5} 31.00$ $\mathrm{kg} / \mathrm{ha}$ and $\mathrm{K}_{2} \mathrm{O} 260.00 \mathrm{~kg} / \mathrm{ha}$.

The experiment consisted of eight treatment combinations $\mathrm{T}_{1}$ (NPK (120:60:60)), $\mathrm{T}_{2}$ NPK (40/120:60:60)+ $\mathrm{ZnSO}_{4}(25 \mathrm{~kg} / \mathrm{ha}), \mathrm{T}_{3}$ NPK (40/120:60:60) + Ammonium molibdate $0.2 \%, \mathrm{~T}_{4}$ NPK (40/120:60:60) +Di-sodiumtetrahydrateoctaborate $0.2 \%, \mathrm{~T}_{5} \mathrm{NPK}(40 / 120$ : $60: 60)+\mathrm{ZnSO}_{4}+$ Ammonium molybdate, $\mathrm{T}_{6} \mathrm{NPK}$ (40/120:60:60) $+\mathrm{ZnSO}_{4}+$ Di-sodiumtetrahydrateoctaborate, $\mathrm{T}_{7}$ NPK (40/120: $60: 60)+$ Ammonium molybdate + Disodium-tetrahydrateoctaborate, $\quad \mathrm{T}_{8} \quad \mathrm{NPK}$ (40/120:60:60) $+\mathrm{ZnSO}_{4}+$ Ammonium molybdate + Di-sodium-tetrahydrateoctaborate.

The experiment was laid out in Randomized Block Designreplicated three times. A Common dose of Nitrogen, Phosphorus \& Potassium at the rate of 120:60:60 kg/ha was applied to all plots in equal proportion, one third Nitrogen and full dose of phosphorous and potassium was applied at the time of transplanting. The remaining nitrogen was applied in two equal splits at tillering and panicle initiation stages. The seedlings were transplanted at a spacing of $20 \mathrm{~cm} \times 15 \mathrm{~cm}$ and one seedling were planted hill ${ }^{-1}$ at a depth of 2-3 cm of 35 days old seedlings were transplanted in the main field. Observations were recorded on grain yield, straw yield, biological yield, harvest index and yield attributing characters. Analysis of variance for individual characters was done by the procedures suggested by Panse and Sukhatme (1985).

\section{Results and Discussion}

\section{Yield attributes}

Application of micro nutrients viz. molybdenum and boron as foliar spray at active tillering stage and panicle initiation stage respectively of rice had profound effect on yield attributing characters i.e. grain yield, straw yield, biological yield and harvest index of hybrid rice under Table-1.

Highest grain yield $\left(6.54 \mathrm{t} \mathrm{ha}^{-1}\right)$, straw yield $(6.79 \mathrm{t} / \mathrm{ha})$ and biological yield (13.33 t/ha) was recorded with NPK (40/120:60:60) + $\mathrm{ZnSO}_{4}+$ Ammonium molybdate + Disodium-tetrahydrateoctaborate.

The yield attributes increased owing to micro nutrients like $\mathrm{Zn}$, Mo and $\mathrm{B}$ fertilization which might took part in metabolism of plants as an activation of several enzymes and in turn directly and indirectly affected the synthesis of carbohydrate and protein. The finding corroborated the reports of Chaudhury et al., (2007), Keram et al., (2014) and Praneeth et al., (2015). Harvest index (49.07) was higher in NPK (40/120:60:60) + Ammonium molybdate + Di-sodiumtetrahydrateoctaborate. This is in confirmation with earlier workers Ramanujam and Rao (1971) and Dewal and Pareek (2000). 
Table.1 Effect of different treatments on grain yield, straw yield, biological yield and harvest index of Hybrid rice cv. KRH-1

\begin{tabular}{|c|c|c|c|c|}
\hline Treatments & $\begin{array}{c}\text { Grain } \\
\text { yield(t/ha) }\end{array}$ & $\begin{array}{c}\text { Straw yield } \\
\text { (t/ha) }\end{array}$ & $\begin{array}{c}\text { Biological yield } \\
\text { (t/ha) }\end{array}$ & Harvest index \\
\hline $\mathbf{T}_{\mathbf{1}}$ & 5.05 & 5.55 & 10.60 & 47.46 \\
\hline $\mathbf{T}_{\mathbf{2}}$ & 5.23 & 5.64 & 10.87 & 48.13 \\
\hline $\mathbf{T}_{\mathbf{3}}$ & 5.42 & 5.94 & 11.36 & 47.71 \\
\hline $\mathbf{T}_{\mathbf{4}}$ & 5.44 & 5.94 & 11.38 & 47.80 \\
\hline $\mathbf{T}_{\mathbf{5}}$ & 5.77 & 5.99 & 12.06 & 47.84 \\
\hline $\mathbf{T}_{\mathbf{6}}$ & 6.18 & 6.56 & 12.74 & 48.51 \\
\hline $\mathbf{T}_{\mathbf{7}}$ & 6.40 & 6.50 & 12.90 & 49.62 \\
\hline $\mathbf{T}_{\mathbf{8}}$ & 6.54 & 6.79 & 13.33 & 49.07 \\
\hline SEM( $\mathbf{n})$ & $\mathbf{0 . 0 6}$ & $\mathbf{0 . 1 2}$ & $\mathbf{0 . 1 6}$ & $\mathbf{0 . 4 3}$ \\
\hline C.D at 5\% & $\mathbf{1 . 0 5}$ & $\mathbf{0 . 3 6}$ & $\mathbf{0 . 4 9}$ & $\mathbf{1 . 3 1}$ \\
\hline
\end{tabular}

t-Tonnes, ha-Hectare

Table.2 Effect of different treatments on yield attributes of Hybrid rice cv.KRH-2

\begin{tabular}{|c|c|c|c|c|c|c|}
\hline Treatments & $\begin{array}{c}\text { No. of } \\
\text { Panicle } \\
\left(\mathbf{m}^{-\mathbf{1}}\right)\end{array}$ & $\begin{array}{c}\text { Length of } \\
\text { panicle } \\
(\mathbf{c m})\end{array}$ & $\begin{array}{c}\text { total grains } \\
\text { (No/panicle) }\end{array}$ & $\begin{array}{c}\text { filled grains } \\
\text { (No/panicle) }\end{array}$ & $\begin{array}{c}\text { Unfilled } \\
\text { grain (No } \\
\text { /panicle) }\end{array}$ & $\begin{array}{c}\text { Test weight } \\
\text { (g/1000 } \\
\text { grains) }\end{array}$ \\
\hline $\mathbf{T}_{\mathbf{1}}$ & 266.67 & 26.76 & 110.00 & 88.00 & 23.00 & 21.44 \\
\hline $\mathbf{T}_{\mathbf{2}}$ & 280.00 & 27.12 & 110.67 & 88.68 & 20.00 & 21.14 \\
\hline $\mathbf{T}_{\mathbf{3}}$ & 280.00 & 27.43 & 120.00 & 95.00 & 18.00 & 21.94 \\
\hline $\mathbf{T}_{\mathbf{4}}$ & 293.33 & 27.65 & 118.00 & 97.00 & 16.00 & 21.83 \\
\hline $\mathbf{T}_{\mathbf{5}}$ & 303.66 & 27.95 & 123.00 & 97.00 & 16.00 & 22.48 \\
\hline $\mathbf{T}_{\mathbf{6}}$ & 320.00 & 27.82 & 116.00 & 98.00 & 16.00 & 22.67 \\
\hline $\mathbf{T}_{\mathbf{7}}$ & 320.00 & 27.90 & 117.00 & 98.00 & 16.30 & 22.29 \\
\hline $\mathbf{T}_{\mathbf{8}}$ & 346.66 & 27.50 & 120.33 & 99.00 & 15.00 & 22.35 \\
\hline SEm( $\mathbf{m})$ & $\mathbf{1 0 . 8 3}$ & $\mathbf{0 . 2 7}$ & $\mathbf{2 . 2 1}$ & $\mathbf{2 . 2 7}$ & $\mathbf{1 . 5 5}$ & $\mathbf{0 . 2 4}$ \\
\hline C.D at 5\% & $\mathbf{3 2 . 7 7}$ & $\mathbf{N S}$ & $\mathbf{6 . 7 1}$ & $\mathbf{6 . 8 8}$ & $\mathbf{4 . 7 0}$ & $\mathbf{0 . 7 5}$ \\
\hline
\end{tabular}

NS-Not significant

Yield Attributing Traits

Application of Mo and B as foliar spray at active tillering (30DAT) and boron at panicle initiation stage (60DAT) of hybrid rice had found effect on yield attributing characters of rice recorded under Table- 2 . The yield attributing characters such as no. of panicles $\mathrm{m}^{-1}$ (10.838) and filled grains panicle ${ }^{-1}(99.00)$ were higher in the same treatment although no. of unfilled grains panicle ${ }^{-1}(15.00)$ was less as compared to others. Length of panicle
$(27.50 \mathrm{~cm})$ and total no. of grains panicle ${ }^{-1}$ (120.33) were increased due to NPK (40/120:60:60) $+\mathrm{ZnSO}_{4}+$ Ammonium molyb date at active tillering stage.

The result confirmed the findings of Ali et al., (2014) and Singh et al., (2000). Test weight (22.35 g) was higher in NPK (40/120:60:60) $+\mathrm{ZnSO}_{4}+$ Di-sodium-tetrahydrateoctaborate applied in panicle initiation stage. Similar effect has also been reported by Sarvanan and Ramanathan (1988). 
Based on the experiment it can be concluded that rice can be cultivated with the application of NPK (40/120:60:60) $+\mathrm{ZnSO}_{4}+$ Ammonium molybdate + Di-sodiumtetrahydrateoctaborate for better yield and yield attributing characters.

\section{References}

Ali, H., Hasnain Z., Shahzad A.N., Sarwar N., Qureshi M.K., Khaliq S. and Qayyum M.F. 2014. Nitrogen and zinc interaction improves yield and quality of submerged basmati rice (Oryza sativa 1.) Not Bot HortiAgrobo, 42(2):372-379.

Alloway, B.I., 2008. Zinc in soils and crop nutrition, $2^{\text {nd }}$ edition published by International Zinc Association and International Association, Brussels Belgium, Paris, France. pp: 223 - 225.

Chaudhury, S.K., Thakur, S.K. and Pandey, A.K.2007. Response of wet land rice (Oryza sativa) tonitrogen and zinc. Oryza, 44: 31-34.

Dewal, G.S., and Pareek, R.G.2000. Effect of phosphorus, sulphur and zinc on growth, yield and nutrient uptake of wheat (Triticumaestivum). Indian Journal of Agronomy.49 (3): 160-162.

Keram, K.S., Sharma, B.L., Sharma, G.D., and Thakur, R.K., 2014. Impact of zinc application on its translocation into plant partsof wheat in a vertisol. The Bioscan.9 (2): 491-495.

Panse, V.G., and Sukatme, P.V. 1985. Statistical methods for agricultural workers, ICAR publication, New Delhi. pp. 359.

Praneeth, K.S., Reddy, S.N., Siva, S.A. and Reddy, Y.S.K. 2015. Effect of zinc nutrition on dry matter production, yield and uptake of zinc by aromatic rice. The Ecoscan.9 (1\&2): 513-516.

Ramanujam, T., and Rao, J.S., 1971. Photosynthesis and dry matter production by rice plant grown under different levels of nitrogen. Madras Agricultural Journal.58: 38-40.

Sarvanan, A., and Ramanathan, K.M., 1988. Effect of zinc application on its availability and yield of rice.Oryza.25: 271-273.

Sen, P.K., and Dasgupta, D.K. 1969. Effect of varying water regimes and levels of nitrogen on the growth and yield of rice. Indian Journal of Agricultural Sciences. 39(1): 1000-1009.

Sharma, A.R., and Das, P.C 1994. Effect of nitrogen fertilization on performance of rice under intermediate deep water condition. Indian Journal of Agronomy. 39(4): 458-552.

Singal, N.C., 2006. Hybrid seed production in field crops, Kalyanipublishers Rajendranagar. Ludhiana - 141008.

Singh, A.K., Amgain, L.P., and Sharma, S.K. 2000. Root characteristics, soil physical properties and yield of (Oryza sativa) as influenced by integrated nutrient management in rice-wheat (Triticum aestivium) system. Indian Journal of Agronomy.45 (2): 217-222.

\section{How to cite this article:}

Shirshendu Samanta, Augustina Saha and Nilanjan Deb. 2017. Effect of Micronutrients on Yield and Yield Attributes of Hybrid Rice under Boro Cultivation in Lower Gangetic Alluvial Zone. Int.J.Curr.Microbiol.App.Sci. 6(10): 3373-3376.

doi: https://doi.org/10.20546/ijcmas.2017.610.395 